WIESŁAWA GIERAŃCZYK

Uniwersytet Mikołaja Kopernika, Toruń

\title{
Kapitał ludzki w przemyśle jako źródło przewagi konkurencyjnej w państwach Unii Europejskiej
}

\section{PodŁoŻE TEORETYCZNE BADAŃ KAPITAŁU LUDZKIEGO}

We współczesnej gospodarce podstawowym źródłem budowania przewagi konkurencyjnej jest kapitał ludzki, który staje się równoważny kapitałowi trwałemu. Pojęcie kapitału ludzkiego występowało już w pracach A. Smitha (1937), który zerwał z założeniem homogeniczności podaży pracy (Schultz 1961) i doszukiwał się podobieństw między zdolnościami i umiejętnościami pracowników a właściwościami kapitału rzeczowego. Z rozgraniczeniem człowieka od jego kapitału, a więc wiedzy i umiejętności w nim zawartych, a będących efektem określonych nakładów, które można pomnażać w trakcie inwestycji, zgadzali się także J.S. Mill, J.R. Walsh, G.S. Baker i in. (za: Domański 1993). T.W. Schulz, który poszukiwał opuszczonych czynników produkcji pozwalających opisać niewyjaśnioną resztę w nowoczesnym wzroście gospodarczym, korzystając również z prac J. Mincera (1958, 1962) i G.S. Beckera (1964), sformułował w latach sześćdziesiątych XX w. podstawy teorii kapitału ludzkiego. Teoria ta w kolejnej dekadzie została wzbogacona i całościowo opracowana przez G.S. Beckera (1976), który odkrył, że znacznej części wzrostu dochodu Stanów Zjednoczonych nie daje się wytłumaczyć wzrostem kapitału rzeczowego. W tym czasie upowszechnił się termin „kapitał ludzki”, którego używano do wyjaśniania roli edukacji i kompetencji w generowaniu koniunktury i wzrostu gospodarczego.

Próby wyjaśnienia charakteru i roli nowych czynników przyrostu produkcji, w tym wiedzy ucieleśnionej w kwalifikacjach i umiejętnościach siły roboczej, podejmowali także C.W. Cobb i P.H. Douglas (1982), M. Abramovitz (1956), J.W. Kendrick (1956), R.M. Solow (1957), E. Denison (1962, 1967), S.G. Strumlin (1968) czy L. Nakamura (2000).

Kapitał ludzki stał się osią endogenicznych modeli wzrostu R.E. Lucasa i P.M. Romera, opierających się na założeniu, że wielkość produkcji jest funkcją kapitału oraz aktualnego poziomu technologicznego. W modelu R.E. Lucasa (1988) jest on takim samym czynnikiem produkcji jak kapitał fizyczny i praca, natomiast P.M. Romer (1990) rozpatruje kapitał ludzki jako czynnik determinujący efektywne wykorzystanie innych czynników produkcji z uwzględnieniem sfery badawczo-rozwojowej (B+R) odpowiadającej za wytwarzanie 
nowych idei. Tak więc $\mathrm{w}$ teoriach endogenicznych pracownicy traktowani są jako twórcze aktywa zdolne do aktywnego oddziaływania i kreowania zmian w procesie produkcji, przyczyniające się do tworzenia dodatkowych wartości (Wyrzykowska 2008) oraz wzrostu produktywności i jakości życia społeczeństwa.

Do pozytywnych empirycznych weryfikacji neoklasycznej teorii wzrostu należą wyniki badań C. Aziardis’a i A. Drazen'a (1990), G.N. Mankiwa, D. Romera i D.N. Weila (1992), N. Gemmella (1996), E.A. Hanushka i D. Kimko (2000), R.J. Barro (2001), A. Bassanniniego i S. Scarpetty'ego (2001), A.B. Kruegera i M. Lindahla (2001), którzy wykazali wpływ kapitału ludzkiego na wzrost gospodarczy, przy czym np. C. Aziardis i A. Drazen udowodnili, że szybki wzrost jest możliwy dopiero po osiągnięciu krytycznego progu wskaźników związanych z jakością czynnika ludzkiego, a np. metoda opracowana przez E.A. Hanushka i D. Kimko i zastosowana przez J. Temple'a (2001) dla krajów OECD nie przyniosła jednoznacznych rezultatów. Zgodne z teorią wyniki uzyskali także J.W. Lee (2001) oraz T. Barrio-Castro i inni (2002), którzy dowodzili wpływu kapitału ludzkiego na całkowitą produktywność czynników produkcji. Odwrotną zależność, a więc wpływ wzrostu gospodarczego na kapitał ludzki, udowodnili natomiast M. Bils i P.J. Klenow (2000).

Z kolei zaprzeczające teorii wzrostu endogenicznego lub wykazujące jej niedoskonałość wyniki badań uzyskali N. Islam (1995) bazujący na specyfikacji G.N. Mankiwa, D. Romera i D.N. Weila, A. De la Fuente i R. Domenech (2000), J. Temple (2001) czy B. Liberda i T. Tokarski (2004). A. De la Fuente i R. Domenech uzyskane wyniki wiązali z niedoskonałością wykorzystywanych baz danych na temat edukacji, ponieważ oszacowany przez nich model bazujący na zbiorze R.J. Barro i J.W. Lee (2001) wyjaśniał zmienność stopy wzrostu produktywności w $80 \%$.

Tło do rozważań nad kapitałem ludzkim stanowi kapitał intelektualny. Problematyka badań nad kapitałem intelektualnym sięga połowy XX w., a termin kapitał intelektualny pojawił się po raz pierwszy w 1958 r. Wprowadzili go analitycy giełdowi N. Kronfeld i A. Rock (za: Edvinsson 2007). Pierwszej analizy kapitału dokonał Karl-Erick Sveiby dopiero w 1989 r. wyodrębniając trzy jego elementy, tj. kompetencje pracowników firm, strukturę wewnętrzną oraz struktury zewnętrzne przedsiębiorstwa. W kolejnych dekadach kapitał intelektualny stał się przedmiotem zainteresowania nie tylko teoretyków, ale także praktyków zarządzania. Wśród teoretyków warto przybliżyć nazwiska badaczy zaangażowanych w poszukiwanie nowych sposobów zarządzania kapitałem intelektualnym i pokrewnym zarządzaniem wiedzą, takich jak: Peter Drucker, Hiroyuki Itami, Ikujiro Nonaka, Hirotaka Takeuchi, David Teece, Brian Hall, Hubert St. Onge, Patrick Sullivan, Thomas Stewart, Gordon Petrash, Thomas H. Devenport, Laurence Prusak, Brauch Lev, Dorothy LeonardBarton, Wendi R. Bukowitz, Ruth L. Williams, Gilbert Probst, Steffen Raub, Kai Romhardt, Kannisto Haanes, Björn Lowendahl, Annie Brooking, Mariusz Bratnicki, Janusz Strużyna, Stefan Kwiatkowski, Bogdan Wawrzyniak (za: Sokołowska 2005). Prób pomiaru i efektywnego wykorzystania kapitału intelektualnego dokonywały nie tylko przedsiębiorstwa (programy zarządzania kapitałem intelektualnym wprowadziły m.in. WM-Data, Skandia AFS, Dow-Chemical, Hughes Aircraft, The Canadian Imperial Bank of Commerce, Celemi, Ernst \& Young, Posco), ale także organizacje odpowiedzialne za ustanawianie i popularyzowanie nowych standardów gospodarczych, m.in. amerykański odpowiednik Komisji Papierów Wartościowych - Securities and Exchange Commision (SEC), Organizacja do Spraw 
Współpracy Gospodarczej i Rozwoju (OECD), Bank Światowy czy Accounting Standards Board i Financial Accounting Standards Board.

Współcześnie większość badaczy jest zgodna, iż podstawę rozważań nad kapitałem intelektualnym należy wyprowadzić od stwierdzenia, że jego budulcem jest wiedza ${ }^{1}$. Wszystkie elementy składowe kapitału intelektualnego (patenty, potencjał innowacyjny, lojalność klientów, reputacja, chęć działania, zaangażowanie, kultura organizacyjna itd.) istnieją dzięki jakiejś postaci wiedzy. Wiedza pochodzi z umysłów ludzi i dzięki umysłom ludzi może być stosowana. Dzięki niej można przetwarzać wszelkiego rodzaju materiały i czynić je bardziej wartościowymi. Stąd też wywodzi się określenie kapitał intelektualny, gdyż zaobserwowano, że pewne niematerialne aktywa, często trudne do określenia, ale z pewnością związane z wiedzą, a raczej będące wynikiem zastosowania wiedzy, przysparzają korzyści i to w stopniu większym niż tradycyjne postacie kapitału, kapitał rzeczowy czy finansowy. Tak więc wiedza ujmowana jako inwestycja² staje się kapitałem (za: Bal-Woźniak 2004). Jednak wiedza zostaje uznana za kapitał intelektualny dopiero wówczas, gdy znajdzie się po stronie aktywów firmy (Pulic 1998).

W związku z tym, że w skład kapitału intelektualnego wchodzą talenty, umiejętności poszczególnych osób oraz grup ludzi, sieci technologiczne i społeczne wraz z oprogramowaniem czy otoczeniem kulturowym, które je łączy, własności intelektualne w postaci patentów, praw autorskich, metod, procedur itd. dzieli się na kapitał:

- ludzki, który obejmuje kompetencje i umiejętności pracowników,

- strukturalny, składający się z kapitału organizacyjnego (wewnętrznego) - wiedzy zakorzenionej w obszarach procesów organizacyjnych i innowacji,

- relacyjny (zewnętrzny), będący efektem dobrych relacji personelu organizacji z klientami i partnerami na rynkach, a także wizerunku przedsiębiorstwa (Williams 2001).

Kapitał ludzki jest zintegrowany z człowiekiem (pracownikiem), jego wiedzą, zdolnościami, umiejętnościami, wykształceniem, predyspozycjami zawodowymi, rutyną, jego przedsiębiorczością, innowacyjnością, powiązaniami z klientami, dostawcami, współpracownikami oraz działaniami w firmie. Kapitał ludzki jest wspierany przez kapitał strukturalny w postaci sprzętu, baz danych, infrastruktury komunikacyjnej i technicznej.

Mimo podejmowania wielu badań kapitał ludzki jest nadal pojęciem, którego definiowanie budzi wiele kontrowersji i wątpliwości. Początkowo utożsamiany był z poziomem edukacji społeczeństwa, współcześnie obejmuje również wskaźniki opisujące badania naukowe i rozwój technologiczny, w najszerszym zaś znaczeniu do pojęcia tego zalicza się także poziom zdrowotności społeczeństwa (Liberda 2004). W Polsce kapitał ludzki jest na ogół definiowany jako zasób wiedzy, umiejętności, zdrowia i energii witalnej zawarty w danym narodzie (Domański 1993) lub całokształt umiejętności fizycznych człowieka, ale także jego zdolności psychicznych i intelektualnych, które mogą być przez niego wykorzystywane w procesie aktywnego udziału w życiu gospodarczym (Rzeszotarska 2002). Zasadniczo pojęcie kapitału ludzkiego, w przeciwieństwie do terminu zasoby ludzkie, podkreślającego

${ }^{1}$ Dla jasności wywodu użyto określenia, iż wiedza pochodzi z umysłu ludzi. W istocie zagadnienie jest bardziej złożone ze względu na występowanie wiedzy w różnych postaciach. Oprócz wiedzy rozumowej (dostępnej, metafizycznej, obiektywnej), występuje wiedza doświadczalna (ukryta, fizyczna, subiektywna). Szerzej na ten temat zob. Bateson 1973 (za: Bal-Woźniak 2004).

${ }^{2}$ Ch. Handy (1996) rozwija to zagadnienie pod hasłem ,inwestycja w inteligencję". 
aspekty ilościowe (liczba ludności, godziny pracy), koncentruje się na aspektach jakościowych, takich jak wiedza i umiejętności.

Kapitał ludzki (kategoria dynamiczna, jakościowa, umożliwiająca tworzenie nowych wartości) jest zatem pojęciem szerszym niż zasoby ludzkie (kategoria statyczna, ilościowa - Kowalewski 2005), ponieważ kapitał ludzki obejmuje nie tylko wielkość i wieloraką strukturę zasobów pracy, ale także ich jakość (Kosiedowski 2008). We współczesnym świecie kwestie jakościowe nabierają coraz większego znaczenia. Na człowieka jako źródło wiedzy kierowane są coraz większe nakłady. Jedynie bowiem podmioty odpowiednio wyposażone w wiedzę i umiejętności są w stanie konkurować o bieżącą dominację i korzyści ekonomiczne oraz długofalowe perspektywy rozwoju.

Do podstawowych czynników determinujących jakość kapitału ludzkiego zalicza się nakład czasu poświęconego samorozwojowi, nakład pieniądza oraz nakład usług specjalistycznych sektorów: edukacyjnego, ochrony zdrowia, badań naukowych, których jakość zależy od nakładów kierowanych na te sektory.

Według podejścia prezentowanego przez OECD kapitał ludzki stanowi tę część kapitału społecznego, którą reprezentują liczba, jakość i struktura zasobów ludzkich, zarówno zatrudnionych, jak i posiadających przygotowanie do zatrudnienia w pracach $\mathrm{B}+\mathrm{R}$ i/lub w sferze bezpośredniego oddziaływania nauk ścisłych i technicznych (Human Resources Devoted to Science and Technology $-\mathrm{HRST})^{3}$. Relacje między kapitałem ludzkim utożsamianym z zasobami ludzkimi dla nauki i techniki, a kapitałem ludzkim związanym z obszarem prac B+R opierają się na zasadzie, że wszystkie osoby odpowiadające kryteriom zasobów ludzkich dla nauki $i$ techniki mogą uczestniczyć $w$ pracach $\mathrm{B}+\mathrm{R}$, natomiast $\mathrm{w}$ pracach $\mathrm{B}+\mathrm{R}$, poza osobami stanowiącymi zasoby ludzkie dla nauki i techniki, mogą brać udział np. przedstawiciele nauk społecznych i humanistycznych, których rola w GOW jest istotna przede wszystkim z punktu widzenia innowacji społecznych, w których uzewnętrzniają się m.in. przemiany cywilizacyjne będące pochodną innowacji technicznych.

\section{WYKSZTALCENIE ZASOBÓW LUDZKICH W PRZEMYŚLE PAŃSTW UNII EUROPEJSKIEJ}

Biorąc pod uwagę mechanizmy rozwoju gospodarczego rządzące współczesnym światem należy stwierdzić, że o sukcesie gospodarczym w większym stopniu decyduje nie ilość, a jakość dostępnych zasobów ludzkich. Jakość kapitału ludzkiego w znacznej mierze jest pochodną wykształcenia społeczeństwa danego państwa. Jak wynika z przeglądu literatury, w teorii kapitału ludzkiego szeroko rozumiane kształcenie zajmuje priorytetowe miejsce (Balcerowicz 1997), ponieważ decyduje o zdolności do adaptacji kapitału finansowego i przetwarzania go w dobra i usługi. R.R. Nelson i S. Phelps (1966) wskazują, że wykształcenie ma największe znaczenie przy implementacji i adaptacji nowych rozwiązań technologicznych, kreacji rozwiązań wcześniej nieznanych oraz realizacji funkcji wymagających przystosowania do zmian.

${ }^{3}$ Szczegółowe omówienie problematyki tej części kapitału ludzkiego wraz z definicjami - por. The Measurement of Scientific and Technological Activities. Manual on the Measurement of Human Resources Devoted to $\mathrm{S} \& \mathrm{~T}, 1995$. 
Wykształcenie predestynuje do przetwarzania i interpretacji strumienia informacji oraz tworzenia nowej jakościowo wiedzy. Jednocześnie ludzie o wyższym poziomie wykształcenia zgłaszają wyższy popyt na nowe rozwiązania rynkowe, które pomnażają przychód z kapitału w nich obecnego. Kapitał wykształcenia wyrażony przez poziom wiedzy społeczeństwa wraz z nagromadzoną wiedzą naukową, czyli skumulowanymi wynikami badań naukowych tworzy według L. Zienkowskiego (2003) kapitał wiedzy, który według T. Kowalewskiego (2006) obok zasobów środków trwałych i kapitału wiedzy naukowej jest determinantą osiągniętego poziomu rozwoju. Należy przy tym podkreślić, że w przedsiębiorczym społeczeństwie ludzie stają przed ciągłym wyzwaniem potrzeby uczenia się i odnawiania wiedzy.

Z gospodarczego punktu widzenia istotne są wykształcenie oraz umiejętności, którymi dysponują ludzie w wieku produkcyjnym, którzy mogą i chcą pracować. Wyodrębnienie segmentu rynku kadr z wyższym wykształceniem mieści się w kanonach teorii segmentacji rynku pracy ${ }^{4}$, która zakłada, że rynek pracy ma charakter heterogeniczny. Procesowi podziału rynku pracy na segmenty sprzyjają zróżnicowanie popytu na pracę oraz ograniczone możliwości mobilności zawodowej i geograficznej pracowników reprezentujących rozmaite cechy zawodowo-społeczne różnicujące podaż pracy (Maniak 2001).

Przyjmuje się, że im wyższe jest wykształcenie, tym większe są umiejętności zawodowe, dlatego wraz ze wzrostem wykształcenia danej społeczności rośnie efektywność pracy. Wykwalifikowana siła robocza lepiej radzi sobie z kreowaniem i absorbowaniem nowych technologii, a co za tym idzie i z postępem technicznym, który z kolei jest ważnym czynnikiem w światowej konkurencji. To dzięki wiedzy, jak pisze L.C. Thurow (2006, s. 123), powstają przełomowe technologie tworzące warunki nierównowagi, w których możliwe są duże zyski i szybkie tempo wzrostu. Stąd osoby zajmujące się lub potencjalnie mogące zająć się pracą związaną z tworzeniem, rozwojem, rozpowszechnianiem i zastosowaniem wiedzy naukowo-technicznej należą do najcenniejszych zasobów działalności przedsiębiorczej na poziomie kraju, regionu, przedsiębiorstwa czy jakiejkolwiek organizacji.

Dla rozwoju gospodarki wiedzy i przemysłu odpowiadającego tym wyzwaniom, kluczowe znaczenie mają te zasoby ludzkie, które legitymują się wykształceniem pozwalającym zajmować się pracą twórczą, rozwojem, upowszechnianiem i zastosowaniem wiedzy naukowo-technicznej (HRST - Human Resources for Science and Technology). Wyróżnia się dwa sposoby identyfikowania zasobów ludzkich dla nauki i techniki. Pierwszy sposób obejmuje zasób siły roboczej dla nauki i techniki według posiadanych kwalifikacji, a drugi według wykonywanego zawodu. Według pierwszego kryterium do populacji zasobów ludzkich dla nauki i techniki zalicza się osoby posiadające formalne wykształcenie określane mianem trzeciego stopnia, czyli wykształcenie ponadśrednie ${ }^{5}$. Do ich wyodrębnienia według poziomu kwalifikacji Podręcznik Canberra zaleca stosowanie klasyfikacji ISCO (International Standard Classification of Occupations), tj. Międzynarodowej Standardowej Klasyfikacji Zawodów. Biorąc pod uwagę obydwa kryteria, w europejskiej statystyce zasobów ludzkich nauki i techniki (HRST) wyróżnia się trzy grupy zasobów siły roboczej (Science, technology and innovation in Europe, 2007, Eurostat, European Commission 2007, s. 128):

${ }^{4}$ Przegląd klasycznych i alternatywnych poglądów dotyczących wyodrębniania tzw. częściowych rynków pracy, kryteriów i konsekwencji segmentacji dla rynku pracy zawarty jest w wielu pozycjach, m.in. Domański 1987, Pocztowski 1991, Kryńska 1996, Kwiatkowski 1992, Włodarski 1992.

${ }^{5}$ wykształcenie średnie - posiadają osoby, które ukończyły szkołę ponadpodstawową (na podbudowie 8-klasowej szkoły podstawowej) lub ukończyły szkołę ponadgimnazjalną z wyjątkiem zasadniczej szkoły zawodowej. 
- osoby posiadające formalne wykształcenie określane mianem trzeciego stopnia, czyli wykształcenie ponadśrednie - HRSTE (Human Resources for Science and Technology in terms of Education),

- osoby posiadające zawody wymagające wyższego wykształcenia oraz zgodnie z ISCO-88 specjaliści, technicy i inny średni personel - HRSTO (Human Resources for Science and Technology in terms of Occupation),

- pracownicy, którzy ukończyli studia wyższe w zakresie nauk ścisłych i technicznych i pracują w sferze nauka i technika - HRSTC (Core of Human Resources in Science and Technology).

W niniejszym opracowaniu wyodrębniono ponadto kategorię naukowców i inżynierów - SE (Scientists and Engineers).

Tab. 1. Absorpcja zasobów ludzkich dla nauki i techniki (HRST)

w przetwórstwie przemysłowym Unii Europejskiej w 2008 r. Dane w procentach

\begin{tabular}{|l|c|c|c|c|c|}
\hline \multirow{2}{*}{$\begin{array}{c}\text { Zasoby ludzkie dla nauki } \\
\text { i techniki (HRST) }\end{array}$} & Średnia & $\begin{array}{c}\text { Współczynnik } \\
\text { zmienności - Vs }\end{array}$ & Max. & Min. & \multirow{2}{*}{ Polska } \\
\cline { 2 - 5 } HRST & 13,6 & 30,2 & $18,4-\mathrm{CZ}$ & $3,4-\mathrm{LU}$ & 12,7 \\
\hline HRSTE & 12,6 & 31,7 & $18,1-\mathrm{DE}$ & $3,2-\mathrm{LU}$ & 11,5 \\
\hline HRSTO & 12,7 & 31,9 & $18,1-\mathrm{CZ}$ & $3,7-\mathrm{LU}$ & 11,6 \\
\hline HRSTC & 10,5 & 34,4 & $15,7-\mathrm{DE}$ & $2,6-\mathrm{CY}$ & 9,4 \\
\hline SE & 18,4 & 42,0 & $28,9-\mathrm{FR}$ & - & 11,0 \\
\hline
\end{tabular}

Źródło: opracowanie własne na podstawie danych Eurostatu

Z przeprowadzonych analiz wynika, że w latach 2000-2008 poziom absorpcji zasobów ludzkich dla nauki i techniki (HRST) do przemysłu w UE, rozumianej jako udział ogólnych zasobów ludzkich dla nauki i techniki i poszczególnych ich kategorii pracujących w przemyśle, utrzymywał się na zbliżonym poziomie. W 2008 r. w przemyśle UE pracowało 13,6\% zasobów ludzkich dla nauki i techniki, przy czym najwyższy poziom absorpcji dotyczył naukowców i inżynierów $(18,4 \%)$, a najniższy pracowników, którzy ukończyli studia wyższe w zakresie nauk ścisłych i technicznych i pracują w sferze nauki i techniki (HRSTC - 10,5\%). Badany obszar okazał się dość jednolity wewnętrznie pod względem wykorzystania w przemyśle zasobów ludzkich dla nauki i techniki, na co wskazują stosunkowo niskie wartości współczynnika zmienności. Najwyższe udziały zasobów ludzkich dla nauki i techniki i poszczególnych ich kategorii odnotowano w Niemczech (DE), Czechach (CZ) i Francji (FR), najniższe natomiast w Luksemburgu (LU) i na Cyprze (CY - tab. 1). Zauważa się, że nieco wyższymi wskaźnikami absorpcji zasobów ludzkich dla nauki i techniki w przemyśle niż średnio w UE odznaczały się kraje „nowej” UE. W 2008 r. w Czechach (CZ) i Słowenii (SL) udział zasobów ludzkich dla nauki i techniki pracujących w przemyśle w ich ogólnych zasobach był o ponad $4 \%$ wyższy aniżeli średnio w UE. Pod względem absorpcji zasobów ludz- 
kich dla nauki i techniki, obok Niemiec wysokimi udziałami pracowników, którzy ukończyli studia wyższe w zakresie nauk ścisłych i technicznych i pracują w sferze nauka i technika w przemyśle w ogólnej liczbie tych zasobów odznaczały się także Rumunia (RO) i Estonia (EE - o 2,6-2,7\% wyższymi niż średnio w UE). W 2008 r. największe zróżnicowanie UE wśród badanych kategorii zasobów ludzkich dla nauki i techniki odnotowano pod względem udziału naukowców i inżynierów pracujących w przemyśle w ogólnej ich liczbie. Obok Francji, ponad 1/4 naukowców i inżynierów zatrudniano w przemyśle Słowenii, Niemiec i Rumunii.

Tab. 2. Nasycenie zasobami ludzkimi dla nauki i techniki (HRST) pracujących w przetwórstwie przemysłowym Unii Europejskiej w 2008 r. Dane w procentach

\begin{tabular}{|l|c|c|c|c|c|}
\hline $\begin{array}{c}\text { Zasoby ludzkie } \\
\text { dla nauki i techniki } \\
\text { (HRST) }\end{array}$ & UE & $\begin{array}{c}\text { Współczynnik } \\
\text { zmienności } \\
- \text { Vs }\end{array}$ & Min. & Max. & Polska \\
\hline HRST & 30,1 & 30,7 & $11,3-$ PT & $42,8-$ FI & 21,2 \\
\hline HRSTE & 19,1 & 45,1 & $6,6-$ PT & $33,9-$ IE & 13,5 \\
\hline HRSTO & 21,5 & 31,1 & $9,0-$ PT & $32,7-\mathrm{DK}$ & 15,6 \\
\hline HRSTC & 10,5 & 41,4 & $4,3-\mathrm{PT}$ & $19,1-\mathrm{FI}$ & 7,9 \\
\hline SE & 5,5 & 57,0 & $1,8-\mathrm{PT} / \mathrm{SK}$ & $11,4-\mathrm{FR}$ & 3,1 \\
\hline
\end{tabular}

Źródło: opracowanie własne na podstawie danych Eurostatu

Nieco większe zróżnicowanie odnotowano w UE pod względem nasycenia pracujących w przemyśle zasobami ludzkimi dla nauki i techniki, rozumianego jako ich udział w ogólnej liczbie pracujących w przemyśle. Empiryczny obszar zmienności udziału zasobów ludzkich dla nauki i techniki w ogólnej liczbie pracujących w przemyśle w UE w 2008 r. wyniósł 31,5\%. Jednocześnie zauważa się, że w analizowanym okresie nasycenie pracujących w przemyśle zasobami ludzkimi dla nauki i techniki w UE systematycznie wzrastało (poza Litwą i Bułgarią, gdzie w latach 2000-2008 ich udział w ogólnej liczbie pracujących w przemyśle spadł odpowiednio z 39,9\% w 2000 r. do 28,4\% w 2008 r. i z 20,7\% w 2000 r. do $18,2 \%$ w 2007 r.). W analizowanym okresie liderem pod względem zaangażowania zasobów ludzkich dla nauki i techniki w przemyśle pozostawała Finlandia (FI), w której udział zasobów ludzkich dla nauki i techniki wśród pracujących w przemyśle stanowił ok. 40\%. Najniższy poziom tego wskaźnika (niemal trzykrotnie niższy niż średnio w UE) odnotowano natomiast $\mathrm{w}$ Portugalii (11,3\%). W Polsce także nasycenie pracujących w przemyśle zasobami ludzkimi dla nauki i techniki było we wszystkich kategoriach niższe niż średnio w UE.

Analiza danych wskazuje na utrzymujący się dystans między krajami „starej” i „nowej" Unii pod względem nasycenia pracujących w przetwórstwie przemysłowym zasobami ludzkimi dla nauki i techniki. Jest to zjawisko niekorzystne, ponieważ obecnie budowanie gospodarki, której podstawę rozwoju stanowi coraz efektywniej tworzona, przyswajana, przekazywana i wykorzystywana wiedza, obok stymulowania i permanentnego rozwijania kapitału ludzkiego, warunkowane jest zdrowymi stosunkami wytwórczymi, które pozwalają kapitał ludzki efektywnie zagospodarować. 
Tab. 3. Zmiany absorpcji i nasycenia zasobami ludzkimi dla nauki i techniki (HRST) w przetwórstwie przemysłowym w latach 2000-2008 w państwach UE. Dane w procentach

\begin{tabular}{|c|c|c|}
\hline Państwa Unii Europejskiej & $\begin{array}{c}\text { Absorpcja HRST } \\
\text { w przetwórstwie przemysłowym }\end{array}$ & $\begin{array}{c}\text { Nasycenie HRST } \\
\text { w przetwórstwie przemysłowym }\end{array}$ \\
\hline Litwa (LT) & $-2,7$ & $-11,5$ \\
\hline Bułgaria (BL) & $-1,6$ & $-2,5$ \\
\hline Szwecja (SE) & $-3,7$ & $-0,7$ \\
\hline Polska (PL) & $-0,5$ & $-0,1$ \\
\hline Rumunia (RO) & $-3,1$ & 0,8 \\
\hline Cypr (CY) & $-1,7$ & 1,6 \\
\hline Estonia (EE) & $-0,2$ & 1,9 \\
\hline Słowacja (SK) & 1,1 & 1,9 \\
\hline Niemcy (DE) & $-1,9$ & 2,0 \\
\hline Portugalia (PT) & $-2,9$ & 2,1 \\
\hline Luksemburg (LU) & $-4,5$ & 2,7 \\
\hline Słowenia (SL) & $-3,2$ & 3,2 \\
\hline Republika Czeska (CZ) & 1,3 & 3,7 \\
\hline Finlandia (FI) & $-0,9$ & 3,9 \\
\hline Malta (MT) & $-3,2$ & 4,4 \\
\hline Węgry (HU) & 1,0 & 4,5 \\
\hline Holandia (NL) & $-1,2$ & 5,2 \\
\hline Grecja (GR) & $-0,3$ & 5,6 \\
\hline Wielka Brytania (UK) & $-3,6$ & 6,3 \\
\hline Łotwa (LV) & $-1,1$ & 6,6 \\
\hline Belgia (BE) & $-0,9$ & 7,0 \\
\hline Włochy (IT) & 1,3 & 7,6 \\
\hline Austria (AT) & $-0,1$ & 9,4 \\
\hline Dania (DE) & $-1,1$ & 9,8 \\
\hline Hiszpania (ES) & $-0,9$ & 10,2 \\
\hline Irlandia (IE) & $-2,3$ & 11,6 \\
\hline Francja (FR) & $-1,1$ & 12,0 \\
\hline
\end{tabular}

Źródło: opracowanie własne na podstawie danych Eurostatu

Z przeprowadzonych badań wynika, że w państwach UE w badanym okresie pomiędzy absorpcją zasobów ludzkich dla nauki i techniki a stopniem nasycenia pracujących w przemyśle tymi zasobami zachodziła dodatnia zależność korelacyjna, ale siła związku pomiędzy zmiennymi była niska i systematycznie spadała ( $\mathrm{z} r=0,301 \mathrm{w} 2000 \mathrm{r}$. do $\mathrm{r}=0,200 \mathrm{w} 2008 \mathrm{r}$.). Zauważa się, że w badanym okresie w państwach UE, poza Włochami, Czechami, Słowacją i Węgrami, nastąpił spadek udziału zatrudnienia w przemyśle w odniesieniu do ogólnych 
zasobów ludzkich dla nauki i techniki (tab. 3). Jednocześnie w większości analizowanych państw zaobserwowano wzrost ich udziału w ogólnym potencjale pracujących w przemyśle. Zjawisko to miało odwrotny kierunek jedynie na Litwie, w Bułgarii, Szwecji i Polsce (tab. 3).

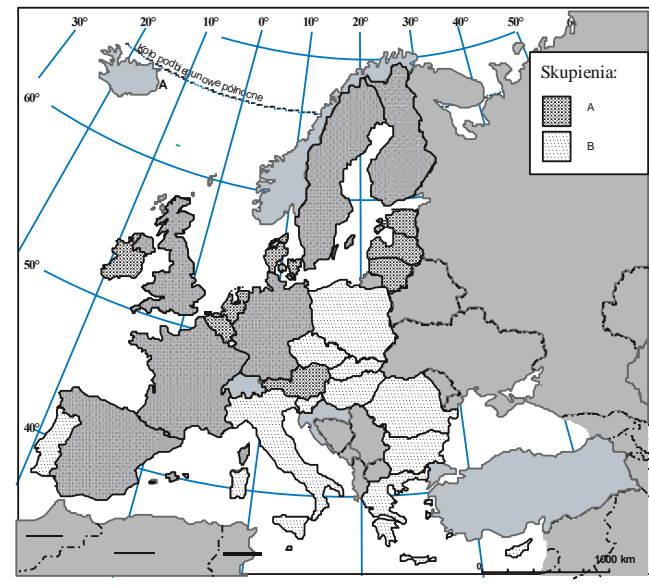

$2000 \mathrm{r}$.

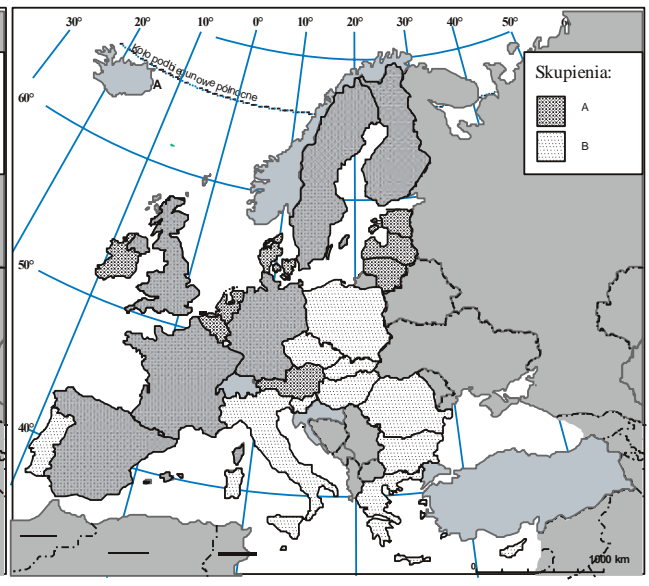

$2008 \mathrm{r}$.

Ryc. 1. Podobieństwo państw europejskich w zakresie absorpcji i nasycenia pracujących zasobami ludzkimi dla nauki i techniki w przemyśle w 2000 i 2008 r.

Źródło: opracowanie własne na podstawie danych Eurostatu

Przeprowadzona analiza podobieństwa państw UE w zakresie omawianych zmiennych wykazała, że w analizowanym okresie nie zaszły istotne zmiany pod względem zagospodarowania kapitału ludzkiego w przetwórstwie przemysłowym. W 2008 r., podobnie jak w 2000 r., odmienne od siebie pozostawały zasadniczo kraje „starej” (skupienie A) i „,nowej” (skupienie B) UE. Skupienie A wyróżniał nieco wyższy niż średnio w UE udział zasobów ludzkich dla nauki i techniki w ogólnej liczbie pracujących w przemyśle (tab. 4) oraz średnio wyższy niż w UE udział zasobów ludzkich dla nauki i techniki w potencjale pracujących w przemyśle (w 2000 r. o $6,0 \%$ i w 2000 r. o $7,2 \%$.

Tab. 4. Model średnich grupowych dla skupień państw UE wydzielonych metodą Warda na podstawie absorpcji i nasycenia zasobów ludzkich dla nauki i techniki (HRST) w przetwórstwie przemysłowym w $2008 \mathrm{r}$. Dane w procentach

\begin{tabular}{|c|c|c|c|c|}
\hline \multirow{2}{*}{ Skupienie } & $\begin{array}{c}\text { Absorpcja } \\
\text { HRST }\end{array}$ & $\begin{array}{c}\text { Nasycenie } \\
\text { HRST }\end{array}$ & $\begin{array}{c}\text { Absorpcja } \\
\text { HRST }\end{array}$ & $\begin{array}{c}\text { Nasycenie } \\
\text { HRST }\end{array}$ \\
\cline { 2 - 5 } & \multicolumn{2}{|c|}{2000} & \multicolumn{2}{|c|}{2008} \\
\hline A & 1,03 & 1,25 & 1,03 & 1,25 \\
\hline B & 0,97 & 0,74 & 0,97 & 0,73 \\
\hline
\end{tabular}

Źródło: opracowanie własne na podstawie danych Eurostatu 
Do skupienia B, zarówno w 2000 jak i 2008 r., obok państw nowej UE zakwalifikowały się Włochy, Portugalia, Grecja oraz w 2008 r. Luksemburg (ryc. 1). Przynależność do grupy B wymienionych państw „starej” UE wynikała z bardzo niskiego poziomu adaptacji zasobów ludzkich dla nauki i techniki dla potrzeb przemysłu (Luksemburg) oraz ze znacznie niższego niż w grupie A nasycenia pracujących w przemyśle zasobami ludzkimi dla nauki i techniki (Grecja, Portugalia, Włochy). W 2008 r. Luksemburg wykazywał najniższy na badanym obszarze poziom ich absorpcji do przemysłu $(3,4 \%)$. Wynikało to ze struktury gospodarki Luksemburga, w którym rozwinięty jest przede wszystkim sektor usług, wytwarzający ok. 70\% produktu krajowego brutto, w tym zwłaszcza sektor finansowy. Luksemburg jest jednym z głównych ośrodków finansowych świata o wieloletnim, międzynarodowym doświadczeniu $\mathrm{w}$ realizacji transakcji transgranicznych, w którym swoją siedzibę ma ponad 160 banków. Pozostałe kraje „starej” UE, które znalazły się w grupie B, wykazywały niższy poziom nasycenia pracujących zasobami ludzkimi dla nauki i techniki, ale podobnie jak kraje grupy A cechował je w latach 2000-2008 znaczący wzrost wykorzystania tych zasobów w przemyśle. Spośród nich najwyższym przyrostem udziału zasobów ludzkich dla nauki i techniki w badanym okresie wykazały się Włochy, w których nastąpił głównie wzrost nasycenia pracujących w przemyśle osobami posiadającymi zawody wymagające wyższego wykształcenia oraz zgodnie z ISCO-88 specjalistami, technikami i innym średnim personelem (HRSTO), co oznacza narastającą skłonność siły roboczej w przemyśle do nabywania kwalifikacji zawodowych podyktowaną potrzebami rynku pracy. Niższy niż średnio w krajach „starej” UE stopień nasycenia pracujących w przemyśle zasobami ludzkimi dla nauki i techniki we Włoszech wynika z nierównomierności w rozwoju przemysłowym pomiędzy regionami południowymi i północnymi. Dzięki znacznym nakładom kapitałowym na infrastrukturę i dużym dotacjom UE gospodarka na południu Włoch w ciągu ostatnich dziesięcioleci uległa znacznej zmianie, jednak nadal charakteryzuje się dużą liczbą małych i średnich przedsiębiorstw, które działają w tradycyjnych sektorach: budowa urządzeń, przemysł spożywczy i rolnictwo. Cechą szczególną działalności takich firm jest uzależnienie od popytu dużych przedsiębiorstw oraz działanie w szarej strefie gospodarki. Są to główne powody niskiego poziomu dostępności nowych technologii w tych branżach, a tym samym ograniczonego popytu na zasoby ludzkie dla nauki i techniki.

Struktura produkcji przemysłowej ze znaczącym udziałem tradycyjnych gałęzi przemysłu była przyczyną stosunkowo niskiego udziału zasobów ludzkich dla nauki i techniki w strukturze pracujących Grecji i Portugalii. Obserwowany w latach 2000-2008 wzrost nasycenia pracujących w przemyśle tymi zasobami (o 3-5\%) był podyktowany przede wszystkim wzrostem poziomu wykształcenia kapitału ludzkiego (HRSTE). Podobny model przemian zasobów ludzkich dla nauki i techniki w przemyśle obserwowano na Węgrzech, na Słowacji i w Słowenii, przy czym Słowenię odznaczał wysoki, ok. 5\% udział naukowców i inżynierów. Spośród państw grupy B Słowenia, obecnie najbogatsze państwo spośród nowych członków Unii Europejskiej (w 2008 roku PKB w przeliczeniu na jednego mieszkańca stanowił 74\% średniej Unii Europejskiej), odznaczała się ponadto wysokim, o 50\% wyższym niż w skupieniu A, poziomem absorpcji zasobów ludzkich dla nauki i techniki w przemyśle. Znacząco do wzrostu PKB w Słowenii przyczynia się przemysł produkujący nowoczesne dobra i konkurujący działaniami typu $\mathrm{B}+\mathrm{R}$, zarówno w kraju, jak i za granicą. Rozwój słoweńskiej gospodarki, jak każdej niewielkiej gospodarki na świecie, w istotnym stopniu zależy od obrotów towarowych z zagranicą. Podstawę eksportu Słowenii stanowią wyroby przemysłu chemicz- 
nego i farmaceutycznego, motoryzacyjnego oraz elektroniki, które też znacząco przyczyniają się do tworzenia wartości dodanej. Znani eksporterzy to m.in. Gorenje - producent sprzętu gospodarstwa domowego, Krka - jedna z największych firm farmaceutycznych w Europie oraz Sava - producent ogumienia. Obecnie nowoczesne oblicze gospodarki Słowenii jest efektem przyjętej na początku lat 90 . XX w. proaktywnej polityki gospodarczej ukierunkowanej na poprawę poziomu produktywności i potencjału innowacyjnego. Kontynuacja tej polityki sprawia, że popyt na wykwalifikowanych pracowników, zwłaszcza specjalistów i inżynierów, nadal jest duży. Rosnącej ich absorpcji sprzyjał rozwój branż zaawansowanych technologicznie (przy jednoczesnym spadku wartości produkcji w branżach pracochłonnych) oraz motywujący do podnoszenia kwalifikacji system wynagrodzeń.

Spośród państw „nowej” UE do skupienia A coraz bardziej podobne były Litwa, Łotwa i Estonia. W analizowanym okresie w krajach tych, podobnie jak w całej UE, odnotowano tendencje do spadku absorpcji zasobów ludzkich dla nauki i techniki do przemysłu przy jednocześnie wysokim, wyższym niż średnio w UE ich udziale wśród pracujących w przemyśle. Kraje nadbałtyckie spośród analizowanych typów kapitału ludzkiego odznaczały się wyższym niż pozostałe kraje „nowej” UE udziałem w zasobach pracujących w przemyśle osób posiadających wykształcenie trzeciego stopnia oraz udziałem zatrudnionych naukowców i inżynierów (ok. 28-30\%). Taka struktura zasobów kapitału ludzkiego w przemyśle czyniła te kraje atrakcyjnymi partnerami dla inwestorów zagranicznych, tworząc źródła przewagi konkurencyjnej względem innych państw konkurujących o ten kapitał.

Jednak całościowo $\mathrm{w}$ grupie $\mathrm{B} \mathrm{w}$ badanym okresie nie zaszły istotne zmiany w poziomie nasycenia pracujących w przemyśle zasobów ludzkich dla nauki i techniki. Przy ogólnie wysokim poziomie wykształcenia zasobów siły roboczej wzrosło jedynie nieco bardziej niż w obszarze zasobów ludzkich dla nauki i techniki nasycenie pracujących w przemyśle osobami posiadającymi zawody wymagające wyższego wykształcenia oraz zgodnie z ISCO-88 specjalistami, technikami i innym średnim personelem (HRSTO). Specjalistyczne przygotowanie zawodowe na poziomie średnim i wyższym staje się coraz większym atutem na rynku pracy w państwach, które budują swoją pozycję poprzez rozwój innowacyjnego przemysłu. W badanym okresie państwami, w których odnotowano znaczący spadek nasycenia pracujących w przemyśle osobami posiadającymi zawody wymagające wyższego wykształcenia oraz zgodnie z ISCO-88 specjalistami, technikami i innym średnim personelem (HRSTO) były Bułgaria i Polska. Spadek nasycenia pracujących w przemyśle specjalistami dysponującymi wiedzą pozwalającą na formułowanie i wdrażanie innowacyjnych rozwiązań jest zjawiskiem nietypowym, wskazującym na brak prawidłowych relacji między podstawowymi aktorami kształtującymi poziom innowacyjności kraju, czyli przemysłem, nauką i rządem. Brak tych relacji określa bardzo niski poziom wydatków na $\mathrm{B}+\mathrm{R}$ potwierdzający niską efektywność polityki proinnowacyjnej. W omawianych państwach rząd, który powinien pełnić rolę regulatora $\mathrm{w}$ stosunku do nauki i przemysłu, jest fundatorem $\mathrm{B}+\mathrm{R}$ ukierunkowanych na badania podstawowe, podczas gdy działania rządowe powinny polegać na stymulowaniu wzrostu innowacyjności i zacieśnianiu współpracy sfery nauki i przedsiębiorstw. Działania dotyczące innowacyjności i oddziałujące na przebieg procesów innowacyjnych współcześnie decydują o rozwoju społeczno-gospodarczym. Jak wynika z badań ekonomistów, aż 2/3 wzrostu gospodarczego w krajach rozwiniętych łączy się z wprowadzeniem innowacji (Wolman 2000). Wymienione kraje, czyli Bułgaria i Polska, w 2008 r. pod względem PKB/1 mieszkańca należały do najbiedniejszych w UE, jednocześnie najmniej wydatkujących na 
B+R. W 2008 r. wydatki na badania i rozwój w relacji do PKB wynosiły w Bułgarii 0,47\%, a w Polsce $0,60 \%$, przy średniej dla UE 1,92\%. Zjawisko to można wkomponować w model ubytku kapitału ludzkiego, z czego swoistą „rentę” czerpią państwa „starej” UE, dokąd migruje znaczna część młodej, wartościowej i dobrze wykształconej ludności.

Pracujący W SFERZE BADAWCZO-ROZWOJOWEJ W PRZEMYŚLE PAŃSTW UE

Często różnice $\mathrm{w}$ tempie rozwoju gospodarczego pomiędzy poszczególnymi krajami można wytłumaczyć dostępnością zasobów ludzkich dla nauki i techniki. Jak wynika z przeprowadzonych badań efektywność działalności przemysłowej wyrażona wysokością wartości dodanej na 1 pracującego w 2008 r. była dodatnio skorelowana z nasyceniem pracujących w przemyśle zasobami ludzkimi dla nauki i techniki $(\mathrm{R}=0,574)$, ale więź ta była silniejsza $\mathrm{w}$ odniesieniu do udziału pracujących $\mathrm{w} \mathrm{B}+\mathrm{R} \mathrm{w}$ ogólnej liczbie pracujących w przemyśle $(\mathrm{R}=0,728)$. Oznacza to, że zwiększenie zdolności innowacyjnych i budowanie gospodarki opartej na wiedzy jest możliwe przede wszystkim dzięki dostępności zasobów ludzkich aktywnie zaangażowanych w B+R. Pracujący w sektorze B+R stanowią trzon kapitału ludzkiego, posiadający wiedzę i doświadczenie przyczyniające się do kreatywności pracowników i innowacyjności przedsiębiorstw. Zadania pracujących w sektorze B+R koncentrują się przede wszystkim na tworzeniu wiedzy, która w swej zakumulowanej formie ma być źródłem innowacji przyczyniających się do rozwoju ekonomicznego firmy, dlatego ludzie tworzący specjalistyczną wiedzę stanowią najważniejszy zasób dzisiejszych organizacji, w nich bowiem tkwi wiedza.

Z przeprowadzonych badań wynika, że pomimo, iż prowadzenie samodzielnych badań obarczone jest znacznym ryzykiem niepowodzenia i wymaga wysokich, nieustannie uzupełnianych kompetencji technicznych (Głodek, Gołębiowski 2006), to udział zatrudnionych w B $+\mathrm{R}$ w przemyśle w państwach UE systematycznie wzrasta. Do kreowania wiedzy zakodowanej w firmie niezbędny jest kapitał ludzki, który nie może być oddzielony od jej posiadacza, czyli pracownika firmy. W niniejszym opracowaniu, mając świadomość uproszczenia, przyjęto pracowników $\mathrm{B}+\mathrm{R}$ w ogólnej liczbie pracujących w przetwórstwie przemysłowym jako aktywa intelektualne ${ }^{6}$.

Z przeprowadzonych badań wynika, że przeciętnie na badanym obszarze w $2008 \mathrm{r}$. pracownicy $\mathrm{B}+\mathrm{R}$ stanowili ok. 2,9\% ogółu pracujących w przetwórstwie przemysłowym i udział ten systematycznie wzrastał. Oznacza to, że w dobie serwicyzacji procesów wytwórczych w UE nie neguje się znaczenia czynnika ludzkiego stanowiącego nośnik wiedzy, powszechnie uznawanej za czynnik produkcji, który współcześnie może być wykorzystywany w tym samym czasie przez rożne organizacje pozwalając uzyskać efekt na wielką skalę. Na badanym obszarze nasycenie zasobów ludzkich dla nauki i techniki aktywami intelektualnymi wahało się od ponad 5\% w krajach skandynawskich do mniej niż 0,5\% na Litwie

\footnotetext{
${ }^{6}$ Termin ,aktywa intelektualne” używany jest niekiedy jako synonim terminu „kapitał intelektualny”. Termin ten występuje m.in. w pracy K. Perechudy (1998), według którego aktywa intelektualne stanowią źródło innowacji i reprezentują wartości niematerialne firmy oraz w dokumentach Stowarzyszenia The Society of Management of Canada, gdzie aktywa intelektualne to te oparte na wiedzy, które są własnością firmy i które w przyszłości będą źródłem korzyści dla firmy (Dzinkowski 1999).
} 
$(0,4 \%)$, w Polsce (0,4\%), Rumunii $(0,3 \%)$, na Łotwie $(0,3 \%)$ i w Bułgarii $(0,2 \%)$. Zauważa się przy tym, że rozkład przestrzenny pracowników $\mathrm{B}+\mathrm{R} w$ przemyśle UE był bardzo nierównomierny.

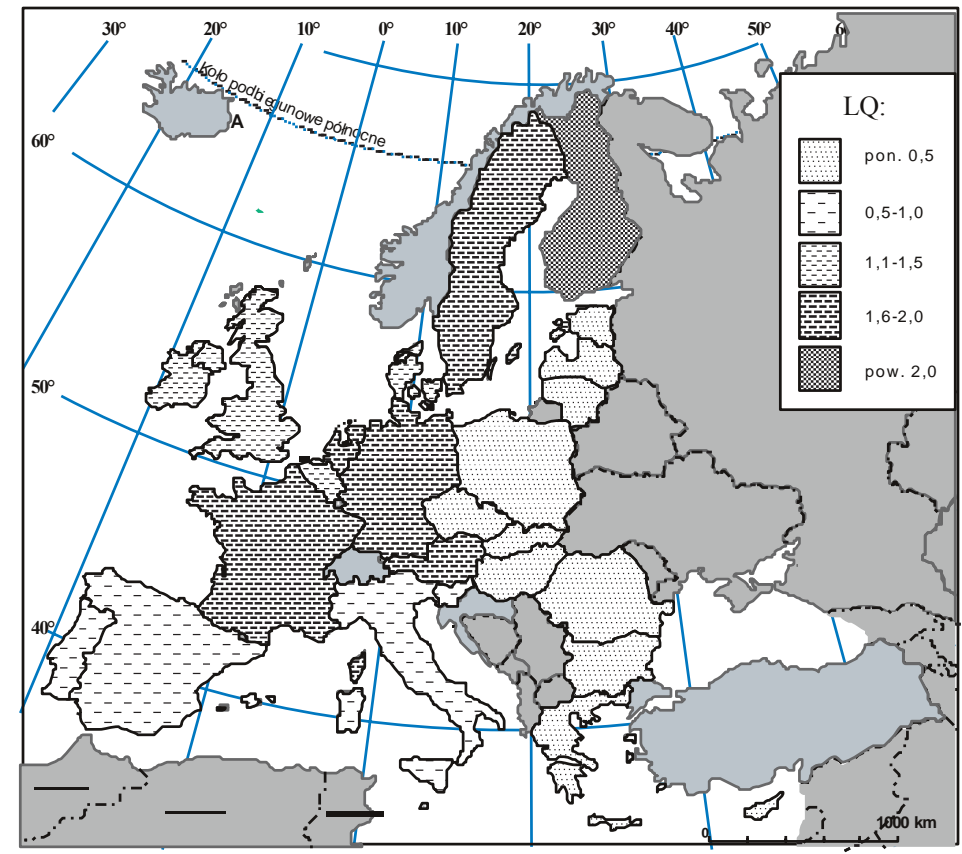

Ryc. 2. Wskaźnik lokalizacji (LQ) pracujących ogółem i pracujących w B+R w przemyśle w państwach UE w $2008 \mathrm{r}$.

\section{Źródło: opracowanie własne na podstawie danych Eurostatu}

Ukazany na ryc. 2 za pomocą wskaźnika lokalizacji (LQ) ${ }^{7}$ rozkład kapitału intelektualnego i zasobów ludzkich w przemyśle państw UE wskazuje, iż trzon badawczo-rozwojowy przemysłu UE koncentruje się w Finlandii, Szwecji, Niemczech, Francji, Austrii i Holandii. Większość państw „nowej” Unii wykazywała LQ poniżej 0,5\%, co oznacza, iż dostępne w tych krajach zasoby ludzkie są w tak niskim stopniu nasycone kapitałem intelektualnym, iż nie są w stanie kształtować innowacyjności i konkurencyjności Wspólnoty.

${ }^{7}$ Wskaźnik lokalizacji (location quotient):

$L Q=\left(E_{i b}^{t} / E_{b}^{t}\right) /\left(E_{i r}^{t} / E_{r}^{t}\right)$, gdzie:

$\mathrm{E}_{i b}=$ pracujący $\mathrm{w}$ przemyśle $\mathrm{w}$ sferze $\mathrm{B}+\mathrm{R} \mathrm{w}$ państwie $i$, w danym okresie $t$,

$\mathrm{E}_{b}=$ pracujący $\mathrm{w}$ przemyśle $\mathrm{w}$ sferze $\mathrm{B}+\mathrm{R} \mathrm{UE} \mathrm{w}$ danym okresie $t$,

$\mathrm{E}_{i r}=$ pracujący $\mathrm{w}$ przemyśle $\mathrm{w}$ państwie $i \mathrm{w}$ danym okresie $t$,

$\mathrm{E}_{r}=$ pracujący w przemyśle w UE w danym okresie $t$. 


\section{WNIOSKI SYNTETYCZNE}

Przemysł Unii Europejskiej pozostaje bardzo zróżnicowany pod względem wykorzystania kapitału ludzkiego, a zwłaszcza aktywów intelektualnych. W kontekście zawartych W strategii lizbońskiej i strategii Europa 2020 zapisów dotyczących budowania konkurencyjnej gospodarki opartej o innowacyjny przemysł jest to zjawisko niekorzystne, ponieważ z przeprowadzonych badań wynika, że pomiędzy poziomem absorpcji zasobów ludzkich dla nauki i techniki w przemyśle i nasyceniem kapitału ludzkiego pracownikami sfery $\mathrm{B}+\mathrm{R}$ zachodzi silna dodatnia zależność korelacyjna, podobna do tej pomiędzy udziałem pracujących w B+R w ogólnej liczbie pracujących w przemyśle i wysokością wartości dodanej w przeliczeniu na 1 pracującego w przemyśle (tab. 5).

Tab. 5. Zależności korelacyjne między składowymi kapitału ludzkiego w UE w 2006 r.

\begin{tabular}{|c|c|c|c|c|}
\hline & $\mathrm{A}$ & $\mathrm{N}$ & $\mathrm{B}+\mathrm{R}$ & $\mathrm{AV} / 1$ prac. \\
\hline $\mathrm{A}$ & 1,000 & 0,200 & $-0,258$ & $-0,335$ \\
\hline $\mathrm{N}$ & 0,200 & 1,000 & 0,727 & 0,574 \\
\hline $\mathrm{B}+\mathrm{R}$ & $-0,258$ & 0,727 & 1,000 & 0,728 \\
\hline AV/1 prac. & $-0,335$ & 0,574 & 0,728 & 1,000 \\
\hline
\end{tabular}

Źródło: opracowanie własne na podstawie danych Eurostatu

A - absorpcja zasobów ludzkich dla nauki i techniki w przemyśle,

$\mathrm{N}$ - nasycenie zasobami ludzkimi dla nauki i techniki w przemyśle,

$\mathrm{B}+\mathrm{R}$ - nasycenie kapitału ludzkiego pracownikami sfery $\mathrm{B}+\mathrm{R}, \mathrm{AV} / 1$ prac. - wartość dodana brutto na 1 pracującego w przemyśle

Oznacza to, że kluczowe zasoby ludzkie, które legitymują się wykształceniem pozwalającym zajmować się pracą twórczą, rozwojem, upowszechnianiem i zastosowaniem wiedzy naukowo-technicznej odpowiadają wyzwaniom współczesnej gospodarki i stymulują budowanie przewag konkurencyjnych w skali globalnej.

\section{Literatura}

Abramowitz M., 1956, Resources and Output Trends in the United States since 1870, American Economic Review Papers and Proceedings, Vol. 46 (2), s. 5-23.

Aziardis C., Drazen A., 1990, Threshold Externalities in Economic Development, Quarterly Journal of Economics, vol. 105, s. 501-526.

Balcerowicz L., 1997, Socjalizm, kapitalizm, transformacja: szkice z przełomu epok, PWN, Warszawa. Bal-Woźniak T., 2004, Mechanizmy kreacji kapitatu intelektualnego odpowiadajace potrzebom gospodarki opartej na wiedzy, [w:] Nierówności społeczne a wzrost gospodarczy, M.G. Woźniak, (red.) Uniwersytet Rzeszowski, Rzeszów, s. 119-129.

Barrio-Castro T., Lopez-Bazo E., Serrano-Domingo G., 2002, New Evidence on International R\&D Spillovers, Human Capital and Productivity in the OECD, Economics Letters, vol. 77, no 1, s. 41-45. 
Barro R.J., Lee J.W., 2001, International Data on Educational Attainment: Updates and Implications, Oxford University Press, Oxford, 53, s. 541-563.

Barro R.J., 2001, Human Capital and Economic Growth, American Economic Review, 91, s. 12-17.

Bassanini A., Scarpetta S., 2001, Does Human Capital Mater for Growth in OECD Countries? Evidence from Pooled Mean Group Estimates, OECD, Economics Department Working Papers, no 282.

Bateson G., 1973, Steps to an Ecology of Mind, Paladin, London.

Becker G.S., 1964, Human Capital. A Theoretical Analysis with special Reference to Education, Columbia University Press, New York.

Becker G.S., 1976, The Economic Approach to Human Behavior, University of Chicago, Chicago.

Bils M., Klenow P.J., 2000, Does Schooling Cause Growth?, The American Economic Review, 90, s. $1160-1183$.

Cobb C.W., Douglas P.H., 1928, A Theory of Production, American Economic Review, vol. 18 supplement, s. 139-165.

De la Fuente A., Doménech R., 2000, Human Capital in Growth Regressions: How Much Difference Does Data Quality Make?, CEPR, Discussion Paper, no 2466.

Denison E., 1962, The sources of economic growth in the United States and the alternatives before us, Common Economic Development, New York.

Denison E., 1967, Why Growth Rates Differ, Washington Brookings Institute, Washington D.C.

Dobija D., 2003, Pomiar i sprawozdawczość kapitatu intelektualnego przedsiębiorstwa, Wyd. WSPiZ, Warszawa, s. 39-40.

Domański H., 1987, Segmentacja rynku pracy a struktura społeczna, Zakład Narodowy im. Ossolińskich, Wrocław.

Domański S.R., 1993, Kapital ludzki i wzrost gospodarczy, PWN, Warszawa.

Dzinkowski R., 1999, Managing Intellectual Capital, Good Practice Guideline, Issue 28, December 1999, The Institute of Charted Accountants in England and Wales, from the Faculty of Finance and management of the ICAEW.

Edvinsson L., 2007, Zarządzanie zasobami ludzkimi, [w:] Biznes, Biblioteka Gazety Wyborczej, Wyd. PWN, Warszawa, s. 65-67.

Gemmell N., 1996, Evaluating the Impacts of Human Capital Stocks and Accumulation on Economic Growth: Some New Evidence, Oxford Bulletin of Economics and Statistics, 58, s. 9-28.

Głodek P., Gołębiowski M., 2006, Transfer technologii w małych i średnich przedsiębiorstwach. Vademecum innowacyjnego przedsiębiorcy, DjaF, Warszawa, s. 10.

Handy Ch., 1996, Wiek paradoksu. W poszukiwaniu sensu przyszłości, Dom Wydawniczy ABC, Warszawa, s. 188-204.

Hanushek E.A., Kimko D., 2000, Schooling, Labor Quality and the Growth of Nations, The American Economic Review, 90, s. 1184-1208.

Islam N., 1995, Growth Empirics: A Panel Data Approach, Quarterly Journal of Economics, vol. 110, no 4, s. 1127-1170.

Kendrick J.W., 1956, Productivity Trends: Capital and Labor, Review of Economics and Statistics, vol. 38 (3), s. 248-257.

Kosiedowski W., 2008, Wyksztatcenie jako czynnik rozwoju kapitału ludzkiego państw i regionów Europy Środkowowschodniej, [w:] Polityka Unii Europejskiej, red. nauk. D. Kopycińska, Katedra Mikroekonomii Uniwersytetu Szczecińskiego, Szczecin.

Kowalewski T., 2005, Teoretyczne i praktyczne aspekty zarzadzania kapitałem ludzkim $w$ wybranych uczelniach podlaskich, Optimum - studia ekonomiczne, nr 1, s. 104-107.

Kowalewski T., 2006, Zagadnienie kapitału ludzkiego w kontekście funkcjonowaniu banku, [w:] Nierówności społeczne a wzrost gospodarczy. Kapitat ludzki i intelektualny, red. M.G. Woźniak, cz. 2, s. 377-382. 
Krueger A.B., Lindahl M., 2001, Education for Growth: Why and for Whom?, Journal of Economic Literature XXXIX, s. 1101-1136.

Kryńska E., 1996, Segmentacja rynku pracy. Podstawy teoretyczne i analiza statystyczna, Wydawnictwo UŁ, Łódź.

Kwiatkowski E., 1992, Dualna a ortodoksyjna teoria rynku pracy, Studia i Materiały PAN, Warszawa.

Lee J.W., 2001, Education for Technology Readiness: Prospects for Developing Countries, Journal of Human Development, vol. 2, no 1, s. 115-151(37).

Liberda B., Tokarski T., 2004, Kapitat ludzki a wzrost gospodarczy w krajach OECD, Gospodarka narodowa $\mathrm{Nr} 3 / 2004$, Warszawa.

Lucas R.E., 1988, On the Mechanics of Economic Development, Journal of Monetary Economics, 22, s. 3-42, Chicago.

Maniak G., 2001, Wybrane teorie rynku pracy, [w:] Przemiany i perspektywy polityki gospodarczej, red. J. Kaja, Szkoła Główna Handlowa, Warszawa, s. 83-102.

Mankiw G.N., Romer D., Weil D.N., 1992, A Contribution to the Empirics of Economic Growth, The Quarterly Journal of Economics, CVII, s. 407-437.

Mincer J., 1958, Investment in Human Capital and Personal Income, Journal of Political Economy, nr 4/1958.

Mincer J., 1962, On-the-job Training: Costs, Returns and Some Implications, Journal of Political Economy, nr 5/1962.

Nakamura L., 2000, Economics and the New Economy: The Invisible Hand Meets Creative Destruction, Business Review, Federal Reserve Bank of Philadelphia, July/August, s. 15-30.

Nelson R.R., Phelps S., 1966, Investment in Human. Technological Difusion and Economics Growth, American Economic Review, vol. 56, s. 69.

Nonaka I., Takeuchi H., 1995, The Knowledge-Creating Company. How Japanese Companies Create the Dynamic of Innovation, Oxford University Press, New York-Oxford.

Perechuda K., 1998, Metody zarządzania przedsiębiorstwem, Wydawnictwo Akademii Ekonomicznej we Wrocławiu, Wrocław, s. 64-65.

Pocztowski A., 1991, Segmentacja rynku pracy, Zeszyty Naukowe AE w Krakowie, nr 379, Kraków.

Pulic A., 1998, Measuring the Performance of Intellectual Potential in Knowledge Economy (presented in 1998 at the 2nd McMaster World Congress on Measuring and Managing Intellectual Capital by the Austrian Team for Intellectual Potential), http://www.vaic-on.net/start.htm/papers

Romer P.M., 1990, Endogenous Technological Change, The Journal of Political Economy, Journal of Political, vol. 98, s. 71-102.

Rzeszotarska G., 2002, Kapitat ludzki i nowoczesny system edukacji - wzajemne relacje, [w:] Strategia rozwoju społecznej gospodarki rynkowej w Polsce, red. S. Partycki, t. 1, Wydawnictwo Uniwersytetu Marii Curie-Skłodowskiej, Lublin, s. 141.

Schultz T.W., 1961, Investment in Human Capital, American Economic Review, nr 1/1961.

Science, technology and innovation in Europe, 2007, Eurostat, European Commission 2007.

Smith A., 1776, An Inquiry into the Nature and Causes of the Wealth of Nations, vol. I and II, R.H. Campbell, A.S. Skinner (eds), Liberty Fund, Indianopolis (polskie wydanie: Smith A., 1954, Badania nad natura i przyczynami bogactwa narodów, PWN, Warszawa).

Sokołowska A., 2005, Zarządzanie kapitałem intelektualnym $w$ małym przedsiębiorstwie, Fundacja Promocji i Akredytacji Kierunków Ekonomicznych, Polskie Towarzystwo Ekonomiczne, Warszawa, s. 12.

Solow R.M., 1957, Technical Change and the Aggregate Production Function, Review of Economics and Statistics, vol. 39 (3), s. 312-320.

Strumlin S.G., 1968, The economic significance of national education, UNESCO, Paris. 
Sveiby K.E., 2001, Intellectual capital and knowledge management, http://www.sveiby.com/articles/ IntellectualCapital.html

Temple J., 2001, Growth Effects of Education and Social Capital in the OECD Countries, OECD Economic Studies, vol. 33, s. 57-101.

The Measurement of Scientific and Technological Activities. Manual on the Measurement of Human Resources Devoted to S\&T, Canberra Manual, 1995, OECD, DOC. OECD/GD (95) 77, Paris.

Thurow L.C., 2006, Powiększanie bogactwa. Nowe reguly gry w gospodarce opartej na wiedzy, Helion, Gliwice, s. 123.

Williams S.M., 2001, Intellectual Capital and Traditional Measures of Corporate Performance, S. Mitchell Singapore Management University, http://www.vaic-on.net/start.htm/papers

Włodarski W., 1992, Segmentacja rynku pracy, Polityka Społeczna, nr 2, s. 9-10.

Wolman E., 2000, Rola ośrodków innowacji i przedsiębiorczości w perspektywicznej, innowacyjnej polityce gospodarczej państwa, Ministerstwo Gospodarki, Departament Strategii Gospodarczej, Innowacje, nr 9, www.gazetainnowacje.pl/innowacje9/strona1.htm

Wyrzykowska B., 2008, Pomiar kapitatu ludzkiego w organizacji, Zesz. Nauk. Ekonomika i Organizacja Gospodarki żywnościowej, nr 66, SGGW, Warszawa, s. 159-170.

Zienkowski L., 2003, Gospodarka „,oparta na wiedzy”- mit czy rzeczywistość?, Studia Ekonomiczne, nr 1-2, s. 82.

\section{Human capital in industry as a source of competitive advantage of the $E U$ states}

The paper presents theoretical reflections and a comparative analysis of the quality of human capital in the industry of the EU Member States in 2000 and 2008. As the quality of human capital is largely derived from the public education of a given country, the opportunities to build the country's competitive advantages on the basis of this resource were examined through the prism of absorption by the industry of the overall human capital resources in the economy, and the participation of qualified human resources (Human Resources Devoted to Science and Technology) in the general human resources in the industry. The degree of involvement of human capital in the R\&D activities was also analysed, as those employed in this sphere, having the knowledge and experience that contribute to the creativity of employees and innovation of the companies, are the backbone of human capital.

Dr Wiesława Gierańczyk

Uniwersytet Mikołaja Kopernika, Toruniu

Instytut Geografii

Zakład Geografii Ekonomicznej i Badań Regionalnych

e-mail: wiesia@umk.pl 